\title{
TERAPI PERNAPASAN PADA PENDERITA ASMA
}

Oleh: Sigit Nugroho

Dosen Jurusan Pendidik̨an Kesehatan dan Rekreasi FIK UNY

\section{ABSTRAK}

Asma adalah suatu keadaan di mana saluran napas mengalami penyempitan karena hiperaktivitas terhadap rangsangan tertentu, yang menyebabkan peradangan. Pada penderita asma, penyempitan saluran pernapasan merupakan respon terhadap rangsangan pada paru-paru normal tidak akan mempengaruhi saluran pernapasan. Penyempitan ini dapat dipicu oleh berbagai rangsangan, seperti serbuk sari, debu, bulu binatang, asap, udara dingin dan olahraga. Gejala asma yang paling umum adalah batuk. Batuk umumnya terjadi di malam hari, dini hari, saat cuaca dingin, dan saat beraktivitas fisik. Napas yang terdengar seperti bunyi peluit juga kesulitan bernapas. Gejala asma akan berlangsung selama 2-3 hari, atau bahkan lebih. Setelah serangan asma membaik, penderita akan membutuhkan pereda serangan (reliever) 3-4 kali per hari hingga batuk dan mengi menghilang.

Bagi penderita asma melakukan aktivitas fisik atau kegiatan yang berat dapat menjadi pencetus terjadinya serangan. Lalu bagaimana jika penderita asma melakukan olahraga, olahraga justru diperlukan penderita asma untuk melatih otot dada agar pernapasan menjadi lebih lancar. Olahraga yang bisa dilakukan penderita asmạ bukan olahraga dengan intensitas gerakan yang cepat dan berat. Olahraga yang bisa dilakukan penderita asma antara lain latihan pernapasan, bersepeda dan renang.. Terapi pernapasan bertujuan untuk melatih cara bernapas yang benar, 
melenturkan dan memperkuat otot pernapasan, melatih ekspektorasi yang efektif, meningkatkan sirkulasi, mempercepat asma yang terkontrol, mempertahankan asma yang terkontrol dan meningkatkan kualitas hidup bàgi penderita asma.

Kata kunci: terapi, pernapasan dan asma

Asma merupakan penyakit saluran napas yang ditandai oleh penyempitan bronkus akibat adanya hiper reaksi terhadap sesuatu perangsangan langsung/fisik ataupun tidak langsung. Tanpa pengelolaan yang baik asma akan mengganggu kehidupan penderita dan akan cenderung mengalami peningkatan, sehingga dapat menimbulkan komplikasi ataupun kematian. Walaupun asma merupakan penyakit yang dikenal luas di masyarakat namun kurang dipahami semestinya hingga timbul anggapan dari sebagian dokter dan masyarakat bahwa asma merupakan penyakit yang sederhana serta mudah diobati. Sehingga timbul kebiasaan untuk mengatasi gejala asma hanya terhadap gejala sesak napas dan mengi dengan pemakaian obat-obatan dan bukannya mengelola asma secara lengkap.

Menurut Sri Astuti Suparmanto (1994) mengatakan prevalensi asma pada anak Indonesia cukup tinggi. Meski demikian pemerintah belum memiliki data yang rinci untuk tiap wilayah. Hanya memiliki data pada anak sekolah di beberapa kota besar seperti Medan, Palembang, Jakarta, Bandung, Semarang, Yogyakarta dan Denpasar. Prevalensi pada anak SD berkisar antara 3,7\%-16,4\% sedangkan pada anak SMP di Jakarta 5,8\%. Berdasarkan Survei Kesehatan Rumah Tangga (SKRT) tahun 1996, 
penyakit-penyakit yang menyebabkan sesak napas seperti bronchitis, emfisema dan asma merupakan penyebab kematian ke7 di Indonesia. WHO memperkirakan antara 100-150 juta penduduk di dunia penyandang asma dan diperkirakan jumlahnya terus bertambah sekitar 180.000 setiap tahunnya. Asma terdapat dan tersebar di seluruh tempat di dunia dengan kekerapan bervariasi. Kekerapan yang paling tinggi ditemukan di negaranegara Anglo-Saxon yakni 17-20\%. Di Indonesia belum ada survei nasional, tetapi penelitian yang dilakukan oleh beberapa institusi menunjukkan kekerapan antara 2-7\% (Van, 2004).

Akhir-akhir ini dilaporkan adanya peningkatan prevalensi morbiditas dan moratitas asma di seluruh dunia terutama di daerah perkotaan dan industri. Disebabkan penderita asma ringan dan periodik tidak menyadari mengidap asma dan menduganya sebagai penyakit pernapasan lain atau batuk biasa. Gangguan batuk dan sesak dialami bila ada rangsangan seperti angin malam yang dingin, flu atau iritasi bahan polutif seperti rokok atau asap hingga diduganya semata-mata terjadi akibat rangsangan tersebut. Pemikiran timbul bila napas telah berbunyi atau mengi dan mengganggu kegiatan sehari-hari. Padahal pada saat tersebut mungkin telah terdapat gangguan lanjut berupa emfisema yang merupakan gangguan faal paru hingga perlu menggunakan obat asma secara kontinyu.

Prevalensi yang tinggi menunjukkan bahwa pengelolaan asma belum berhasil. Berbagai faktor menjadi sebab dari keadaan

MEDIKORA Vol. V, No 1, April 2009: 71-91 
yaitu berbagai kekurangan dalam hal pengetahuan tentang asma, kelaziman melakukan diagnosis yang lengkap atau evaluasi pre terapi, sistimatika dan pelaksanaan pengelolaan, upaya pencegdhan dan penyuluhan dalam pengelolaan asma. Mengingat hal tersebut pengelòlaan asma yang terbaik haruslah dilakukan pada saat dini dengan berbagai tindakan pencegahan agar penderita tidak mengalami serangan asma. Untuk meningkatkan pengelolaan asma yang baik hal-hal tersebut harus dipahami dan dicarikan pemecahannya (Zul Dahlan, 2005).

Untuk itulah senam pernapasan didirikan dapat memberikan pelayanan, pendidikan dan pelatihan senam penyembuhan dengan pola olah napas, olah gerak, dan olah batin serta pemanfaatan energi kehidupan untuk kesembuhan orang lain. Sumber energi utama yang dibutuhkan dalam kehidupan manusia adalah udara/oksigen, sebab tanpa oksigen manusia pasti mati. Energi tidak dapat diciptakan dan tidak dapat dimusnahkan. Energi hanya bisa dirubah dari bentuk satu kebentuk yang lain. Energi adalah kemampuan untuk melakukan kerja, $\mathrm{CO}_{2}+$ Karbohidrat + Lemak - Sistem Metabolisme - ATP $=$ Energi $=$ Kerja $)$. Dari hukum-hukum tersebut di tambah kajian ilmu olahraga maka dapat diseimpulkan bahwa ilmu olah pernapasan adalah suatu tata cara mengatur sistem pernapasan dengan disertai tata konsentrasi, tata gerak, fisik untuk mengubah energi udara menjadi energi tertentu yang bermanfaat. Dengan suatu metode yang tepat dan benar energi udara dapat diubah menjadi energi kesehatan, 
penyembuhan, daya tahan, peningkatan vitalitas kerja, konsentrasi, kekuatan batin, tenaga dalam dan fungsi pernapasan (Santosa Giriwijoyo, 2006)

Fungsi senam pernapasan dapat memberikan manfaat yang lebih besar, aman, nyaman dan memperbaiki kualitas hidup seluruh penderita asma karena senam pernapasan merupakan suatu bentuk olahraga yang gerakannya tidak begitu berat (relaks), tapi dapat menyebabkan energi atau tenaga banyak berkurang. Senam pernapasan merupakan olahraga yang intensitas dan frekuensinya yang tepat bagi penderita asma sehingga dengan latihan olahraga senam pernapasan diharapkan dapat bermanfaat untuk mengendalikan dan mengurangi kambuhnya serangan asma.

\section{DEFINISI ASMA}

Asma bronkiale merupakan salah satu penyakit kronik dengan serangan intermiten. Serangan ditandai dengan adanya spasme dari saluran bronkial, pembengkakan dinding bronkial dan banyaknya sekresi lender. Semua keadaan tersebut mengakibatkan timbulnya batuk, bunyi ngik, sesak napas dan rasa kontriksi pada dada (Wara Kushartanti,2002)

Terdapat kesulitan dalam mengetahui sebab dan cara mengontrol asma. Pertama timbul akibat perbedaan perspektif mengenai definisi asma serta metode dan data penelitiannya. Kedua diagnosis asma biasanya berdasarkan hasil kuesioner tentang adanya serangan asma dan mengi saja tanpa disertai hasil tes faal

MEDIKORA Vol. V, No 1, April 2009: 71-91 
paru untuk mengetahui adanya hiperreaksi bronkus (HRB). Ketiga untuk penelitian dipakai definisi asma berbeda-beda. Asma akut (current asthma) bila telah ada serangan dalam 12 bulan terakhir dan têrdapat HRB: asma persisten, bila terus menerus terdapat gejala dan HRB s̀edangkan asma episodik bila secara episodik dijumpai gejala asma tanpa adanya HRB pada tes provokasi.

Keempat, angka kejadian dari penelitian dipengaruhi oleh berbagai faktor dan objek penelitian yaitu faktor lokasi (negara, daerah, kota atau desa), populasi pasien (masyarakat, sekolah, rumah sakit, rawat inap atau rawat jalan) usia (anak atau dewasa) cuaca (kering atau lembab), predisposisi (atopi, pekerjaan), pencetus (infeksi, emosi, suhu, debu dingin, dan kegiatan fisik), dan tingkat berat serangan asma (Woolcock, 1994).

\section{MORBIDITAS ASMA}

Menurut Michel (1995) melaporkan adanya peningkatan prevalensi asma di seluruh dunia secara umum dan khususnya peningkatan frekuensi perawatan pasien di RS atau kunjungan ke emergensi. Penyebab diduga disebabkan peningkatan kontak dan interaksi alergen di rumah (asap, merokok pasif) dan atmosfir (debu kendaraan). Kondisi sosioekonomis yang rendah menyulitkan pemberian tempat yang baik. Prevalensi asma di seluruh dunia adalah sebesar $8-10 \%$ pada anak dan $3-5 \%$ pada dewasa, dan dalam 10 tahun terakhir ini meningkat sebesar 50\%. 
Prevalensi asma di Jepang dilaporkan meningkat 3 kali dibanding tahun 1960 yaitu dari 1,2\% menjadi 3,14\%, lebih banyak pada usia muda. Penelitian prevalensi asma di Australia 1982-1992 yang didasdrkan kepada data atopi, mengi dan HRB menunjukkan kenaikan prevalensi asma akut di daerah lembab dari 4,4\%(1982) menjadi $11,9 \%$ (1992). Singapura dari 3,9\% (1976) menjadi 13,7\% (1987), di Manila 14,2\% menjadi 22.7\% (1987). Data dari daerah perifer adalah sebesar 0,5\% dari 215 anak dengan bakat atopi sebesar 20,5\%, mengi 2\%, HRB 4\% (Woolcock, 1994).

Serangan asma juga semakin berat, terlihat dari meningkatnya angka kejadian asma rawat inap dan angka kematian. Asma juga merubah kualitas hidup penderita dan menjadi sebab peningkatan absen anak sekolah dan kehilangan jam kerja. Biaya asma sebesar 7.000 Milyard di Perancis yaitu 1\% dari biaya pemeliharaan kesehatan langsung ataupun tidak langsung meningkat terus (Michel, 1995).

Menurut Soena Stxmantri (1995) penelitian di Indonesia sering menggunakan kuesioner dan jarang dengan pemeriksaan HRB. Hampir semuanya dilakukan di lingkungan khusus misalnya di sekolah atau rumah sakit dan jarang di lingkungan masyarakat. Dilaporkan pasien asma dewasa di RS Hasan Sadikin berobat jalan tahun 1985-1989 sebanyak $12.1 \%$ dari jumlah 1.344 pasien dan 1993 sebanyak $14,2 \%$ dari 2.137 pasien. Pada perawatan inap 4,3\% pada 1984-1985 dan 7,5\% pada 1986-1989. Pasien asma anak dan dewasa di Indonesia diperkirakan sekitar 38\%, Survai Kesehatan

MEDI KORA Vol. V, No 1, April 2009: 71-91 
Rumah Tangga (SKRT) 1986 mengajukan angka sebesar 7,6\%. Hasil penelitian asma pada anak sekolah berkisar antara $6,4 \%$ dari 4.865 dan $15,15 \%$ dari 1.515 anak.

\section{MASALAH PENGELOLAAN ASMA}

Terdapat berbagai hal yang menimbulkan masalah dalam pengelolaan asma khususnya di Indonesia :

\section{Pengetahuan Yang Kurang Tepat Mengenal Konsep Asma}

a. Para medisi

Pengetahuan patogenesis asma yang benar bahwa peradangan bronkus sebagai faktor dasar asma belum merata, dan belum disadari bahwa mengatasi peradangan bronkus adalah tujuan utama terapi. Asma potensil untuk menjadi penyakit seumur hidup dan harus diperlakukan sebagai penyakit kronik lain seperti DM, dan hipertensi. Belum ada kerjasama berlanjut antara dokter dan pasien dalam upaya penegakan diagnosis dan terapi asma yang benar yang diikuti upaya kelola mandiri dari pasien. Usaha penyuluhan asma yang lebih baik juga masih kurang, hingga tidaklah disadari bahwa komplikasi kematian akibat asma dapat dihindari.

b. Pasien dan masyarakat

Masyarakat masih menganggap asma penyakit tidak bisa disembuhkan, bersifat kronik dan cenderung progresif. Juga tidak mengetahui cara ataupun tidak melaksanakan 
pencegahan dari serangan asma di rumah. Masyarakat umumnya mempunyai pengertian yang salah tentang pemakaian inhaler. Penderita asma memiliki rasa rendah diri dengán asma yang dideritanya. Dan belum terlihat adanya usaha yang baik dalam mengontrol merokok dan menghindari alergen.

\section{Cara Penegakan Diagnosis Asma}

Menjadi anggapan umum bahwa diagnosis asma ditegakkan dengan adanya sesak napas dan mengi (wheezing). Sesungguhnya kriteria diagnosis yang dianjurkan adalah:

a. Anamnesis

Keterangan adanya sesak napas paroksismal yang berulang kali, mengi dan batuk (cenderung timbul pada malam dan dini hari). Gejala hilang pada saat istirahat dan remisi. Adanya faktor predisposisi atau presipitasi.

b. Pemeriksaan penunjang

Didapatkan obstruksi bronkus reversibel yang diketahui dari hasil terapi, tes bronkodilatasi atau perubahan alami; hipersensitifitas bronkus, diketahui dari peningkatan reaksi kontraksi bronkus terhadap acetylcholine, metacholin, histamin, dan lain-lain; adanya predisposisi atopik, peninggian IgE antibodi spesifik terhadap alergen lingkungan; adanya peradangan saluran napas, peningkatan eosinofil sputum, creola bodies (Miyamoyo, 1994)

\section{Evaluasi Asma Pre Terapi}

MEDIKORA Vol. V, No 1, April 2009: 71-91 
Jarang dikerjakan diagnosis atau evaluasi asma pre terapi lengkap sebagai dasar paket pengelolaan asma yang sistimatik dan individual. Biasanya pasien diobati hanya berdasarkan anamtnesis dan pemeriksaan fisik. Pengelolaan asma dalam hal ini ibarat mengobati nyeri dada sebagai suatu penyakit jantung iskemik tanpa melakukan pemeriksaan EKG. Tes faal paru khususnya tes reversibilitas perlu ditekankan sebagai pemeriksaan yang penting untuk diagnosis dan tindak lanjut pengelolaan asma.

Penelitian Internasional menunjukkan bahwa di Inggris, New Zealand, dan Australia pemeriksaan pre terapi Arus Puncak Ekspitusi (APE) pada pasien asma dilaksanakan mendekati $100 \%$, dan pengukuran rekaman rutin harian APE oleh pasien sebesar 42,1\%. Penelitian asma berdasarkan laporan 1.197 dokter Asia termasuk Indonesia (7.1\%) yang terdiri dari pulmonologis, internis, ahli anak dan ahli alergi mendapatkan penegakan diagnosis asma yang dilakukan di Asia (Miyamoyo, 1994).

\section{Sistim Pengelolaan Asma}

Menurut Sheffer (1992) pengelolaan asma belum menyeluruh terhadap berbagai aspeknya secara sistimatik dan kontinyu. Terapi belum tuntas dan umumnya baru ditujukan untuk mengatasi gejala asmanya saja. Pengelolaan secara sistimatis seharusnya mencakup: 
a. Penegakan diagnosis lengkap, tingkat beratnya asma, faktor pencetus dan presipitasi.

b. Kerjasama yang kontinyu antara dokter (klinik/RS) dengan pasich dan lingkungannya (di rumah dan tempat kerja).

c. Upaya mengatasi bronkospasme/serangan dan terapi pencegahan di klinik/RS dan di rumah, pencegahan serangan dengan mengatasi faktor trigger dan inducer.

d. Pilihan obat yang tepat berupa suatu sistim dengan pemilihan steroid sebagai terapi asma utama yang ditujukan untuk mengatasi inflamasi pada semua tingkat asma, kecuali yang paling ringan. Pada waktu ini disarankan terapi asma sebagai berikut: jenisnya adalah CBA (corticosteroid, b2 agonis, aminofilin), terpilih dalam bentuk obat inhalasi, dengan dosis yang adekuat secarateratur, bila perlu kontinyu.

e. Tersedia pedoman tartans bagi pasien untuk pelaksanaan di rumah: membiasakan tindak lanjut dengan pengukuran APE (menggunakan Peak Flow Rate Meter), melaksanakan usaha rehabilitasi atau preventif.

f. Upaya pengelolaan asma yang dilakukan secara gigih dan teratur

MEDIKORA Vol. V, No 1, April 2009: 71-91 


\section{LATIHAN PERNAPASAN}

\section{Latihan Pernapasan}

Terapi pernapasan pada penderita asma dilakukan dengan latihan pernapasan duduk dan pernapasan bergerak. Latihan napas 'pada posisi duduk bagi penderita asma merupakan pengambilan posisi dengan tenang agar mencapai ketenangan yang mendalam, untuk memacu otak menjalankan fungsi secara maksimal karena otak merupakan komando tertinggi bagi tubuh. pelaksanaan, sebagai berikut :

a. Letakan kedua telapak tangan didepan dada, tarik napas perlahan-lahan dan diikuti tarikan kedua telapak tangan perlahan-lahan kesamping sampai otot dada terulur kebelakang lakukan sampai 7 kali.

b. Sama seperti diatas meletakan kedua telapak tangan didepan dada, tetapi dalam menarik napas dan menarik tangan repetisinya lebih cepat sekali tarik sekali frekuensi pernapasan.

Pernapasan bergerak adalah pengolahan pernapasan yang dilakukan bersamaan dengan melakukan gerak. Untuk tingkat dasar dengan 4 gerakan, tiap jurus gerakannya dengan intensitas tinggi kira-kira 2 menit. Pada awal gerakan, napas ditarik sebanyak mungkin melalui hidung, kemudian ditekan dan ditahan dibawa perut sambil menggesek telapak kaki setengah lingkaran dengan gerakan memutar pada posisi tiap penjuru, seiring seirama dengan gerakan tangan. Untuk I kali 
menekan dan menahan napas minimal dilakukan pada tiap penjuru, setelah itu napas dikeluarkan, juga melalui hidung. Setelah semua keempat arah penjuru dilakukan kemudian atur napas dengan tarik dan keluar napas 2 atau 3 kali, lalu dilanjutkan dengan latihan tingkat lanjut.

Intensitas dalam latihan pernapasan ini terdiri dari 2-4-2 yaitu dua menit dengan latihan keras diikuti dengan empat menit latihan ringan dengan durasi selama 30 menit dan frekuensi 3 kali seminggu. Kekhususan di dalam latihan pernapasan adalah: waktu mengeluarkan napas (ekspirasi) dikerjakan secara aktif, sedangkan sewaktu menarik napas, lebih banyak secara pasif. Mengeluarkan napas melalui mulut seperti sewaktu meniup lilin atau bersiul, pelan-pelan, dengan mengkempiskan dinding perut. Sewaktu inspirasi, dinding perut relaks (pasif) dan udara masuk ke paru-paru melalui hidung.

Menurut Wara Kushartanti (2002) latihan bernapas harus dilakukan setiap hari dalam beberapa menit dengan cara sebagai berikut:

a. Hembuskan napas melalui hidung sehingga lendir pada ronkii akan tertarik ke atas.

b. Ambil napas pendek melalui hidung dan hembuskan panjang melalui bibir yang terkatup renggang, sehingga menimbulkan suara.

c. Panjang fase ekspirasi diusahakan dua kali panjang fase inspirasi.

MEDIKORA Vol. V, No 1, April 2009: 71-91 
d. Kendurkan pakaian dan aturlah napas sehinga pada saat ekspirasi perut mengempis, untuk menunjukkan bahwa diafragma meninggi kearah dada. Beritahukan bahwa akan dida batuk dan bunyi ngik selama beberapa detik pertama dari pernapasan diafragma.

e. Minumlah segelas air sebelum dan sesudah latihan.

\section{Manfaat dan Tujuan Latihan Penapasan}

Latihan pernapasan juga merupakan salah satu penunjang pengobatan asma karena keberhasilan pengobatan asma tidak hanya ditentukan oleh obat asma yang dikonsumsi, namun juga faktor gizi dan olah raga. Bagi penderita asma, olah raga diperlukan untuk memperkuat otot-otot pernapasan. Latihan pernapasan bertujuan untuk:

a. Melatih cara bernafas yang benar.

b. Melenturkan dan memperkuat otot pernafasan.

c. Melatih ekspektorasi yang efektif.

d. Meningkatkan sirkulasi.

e. Mempercepat asma yang terkontrol.

f. Mempertahankan asma yang terkontrol.

g. Kualitas hidup lebih baik.

Latihan pernapasan tidak boleh dilakukan sembarangan. Ada syarat-syarat bagi mereka yang akan melakukan latihan, yaitu: tidak dalam serangan asma, sesak dan batuk, tidak dalam serangan jantung, dan tidak dalam keadaan stamina 
menurun akibat flu atau kurang tidur dan baru sembuh, (http://www.medicastore.com).

Menurut Wara kushartanti (2002) program latihan yang dirancang bagi penderita asma pada dasarnya menitik beratkan pada latihan pernapasan yang bertujuan untuk:

a. Meningkatkan efisiensi fase ekspirasi

b. Mengurangi aktivitas dada bagian atas

c. Mengajarkan pernapasaan diafragma

d. Merelakskan otot yang tegang

e. Meningkatkan fleksibilitas otot intercostalis, pectoralis, scalenius, dan trapezius

Pada latihan pernapasan merupakan alternatif sarana untuk memperoleh kesehatan yang diharapkan bisa mengefektifkan semua organ dalam tubuh secara optimal dengan olah napas dan olah fisik secara teratur, sehingga hasil metabolisme tubuh dan energi penggerak untuk melakukan aktivitas menjadi lebih besar dan berguna untuk menangkal penyakit (Wisnu Wardoyo, 2003).

Latihan pernapasan telah banyak dikenal dan mempunyai efek penyembuhan dan amat bermanfaat bagi fungsi korteks serebri, organ abdominal dan untuk pengendalian diri. Di dalam suatu system pernapasan pada waktu frekuensi pernapasan menurun maka kapasitas tidal dan kapasitas vital akan meningkat. Pada meditasi terjadi relaksasi sempurna dari otot-otot tertentu dan kunci utama keberhasilan

MEDI KORA Vol. V, No 1, April 2009: 71-91 
senam pernapasan adalah keteraturan dan kepatuhan melakukan senam tersebut (Laurentia Mihardja, http:/ / digilib.litbang.depkes.go.id).

- Ada beberapa fungsi terapi pernapasan adalah:

a. Mengatur kes̀eimbangan seluruh fungsi organ tubuh

b. Meningkatkan daya tahan terhadap suatu penyakit

c. Memulihkan organ tubuh yang mengalami disfungsional.

d. Mengatur keseimbangan cairan tubuh, aktivitas hormaon, aktivitas enzim, dan laju metabolisme.

e. Mempelancar peredaran darah secara sistemik.

f. Meningkatkan kemampuan gerak tubuh.

g. Meningkatkan ketenangan batin dan percaya diri.

h. Defensive (pertahanan diri)

Sedangan terapi latihan pernapasan diidentifikasikan untuk mengobati:

a. kekurangan gerak yang yang menghasilkan kemunduran kemampuan fungsional alat- alat tubuh dengan gejala antara lain:

1). Kurang mampu pada sikap berdiri (intoleransi orthostatic)

2). Degenerasi tulang-tulang, tulang menjadi keropos (osteoporosis) dan rapuh.

3). Degenerasi jaringan, kurangnya aktifitas menjadi otot mengecil (atrofi). 
4). Pada penderita diabetes, kurangnya aktifitas menyebabkan resistensi terhadap insulin, kadar gula darah lebih sulit dikendalikan. Hal ini akan memperbesar tórjadinya komplikasi.

5). Kurangnya gerak menyebabkan perubahan metabolisme lemak, kadar kolesterol terutama LDL meningkat yang dapat mempertinggi resiko terjadinya penyakit gangguan aliran darah, misalnya jantung koroner dan stroke.

b. Penyakit-penyakit non infeksi

1). Penyakit hipokinetik

2). Penyakit metabolisme (kegemukan diabetes, kelebihan lemak)

3). Penyakit jantung dan pẹbuluh darah (jantung koroner, tekanan darah tinggi/rendah, varises).

4). Penyakit psikosomatis.

c. Untuk penyakit infeksi, dengan terapi latihan senam pernapasan dapat meningkatkan kondisi tubuh, sehingga dapat mempercepat membantu pembentukan antibody terhadap suatu penyakit. Kondisi tubuh yang baik adalah syarat utama pada setiap proses kesembuhan

d. Penyakit-penyakit lain yang dapat membatu kesembuhan dengan terapi senam pernapasan:

1). Gangguan saluran pernapasan (asma bronkiale, pulmonary distonia)

MEDIKORA Vol. V, No 1, April 2009: 71-91 
2). Gangguan pencernaan (maag/gastritis, perut kembung, dan susah buang air besar)

3). Gangguan pada system reproduksi

4). Sakit perut pada saat mentruasi.

5). Mentruasi tidak teratur

6). Sulit tidur (imsonia)

7). Gangguan pada pembulu darah

8). Batu saluran kencing

c. Penyakit-penyakit non medis, dengan melakukan latihan pernapasan pusat-pusat tenaga akan diolah dan pada akhirnya akan membentuk system energi yang mengelilingi tubuh. Sistem energi yang mengelilingi tubuh dengan dibarengi dengan meningkatnya ketenangan batin akan berfungsi sebagai antibody terhadap penyakit non-medis.

\section{KESIMPULAN}

Prevalensi asma meningkat di seluruh dunia. Hal ini disebabkan terutama oleh pengertian yang salah mengenai asma, pedoman dan pelaksanaan pengelolaan asma yang tidak lengkap atau sistimatis, serta sangat kurangnya data dan perencanaan lanjutan. Untuk mengatasi hal tersebut perlu dilaksanakan strategi pengelolaan asma berdasarkan pedoman pengelolaan yang lengkap dan sistimatik. Kerjasama yang erat di antara para dokter dan petugas medik lainnya dengan penderita asma sangatlah diperlukan untuk mencapai hasil yang sebaik-baiknya. Dengan 
upaya ini diharapkan akan tercapai penyebarluasan cara pengelolaan asma preventif dan kuratif yang sesuai dengan perkembangan dan metode pengelolaan asma yang mutakhir. Sehingga tełcapai pula penurunan angka morbiditas maupun mortalitas yang diakibatkan oleh asma ataupun komplikasinya.

Dengan terapi pernapasan diharapkan sebagai alternatif mentode pengolahan asma sehingga memperoleh kesehatan yang bisa mengefektifkan semua organ dalam tubuh secara optimal dan energi penggerak untuk melakukan aktivitas menjadi lebih besar yang berguna untuk menangkal penyakit diantaranya dapat mencegah resiko kambuhnya asma. Intensitas dalam terapi pernapasan pada penderita asma terdiri dari 2-4-2 yaitu dua menit dengan latihan keras diikuti dengan empat menit latihan ringan dengan durasi selama 30 menit dan ditutup dengan latihan pernapasan duduk akhir selama 10 menit frekuensi 3 kali seminggu.

\section{Daftar Pustaka}

Laurentia Mihardja

http:/ / digilib.litbang.depkes.go.id/go.php?id=jkpkbppk-gdlgrey-2004-laurentia-1508-réspirator

Michel FB. Neukirch F. Housyuel J. (1995). Asthma: a world problem of public health. Bull Acad Natl Med

Miyamoyo T, Mikawa H. (1994). Asthma management In Asia. The 8th Allergy and Respiratory Diseases Conference. Life Science Medica Co, Ltd. Marc

MEDIKORA Vol. V, No 1, April 2009: 71-91 
Santosa Giriwijoyo dan Muchtamadji M. Ali. (2006). Ilmu Faal Olahraga Fungsi Tubuh Manusia pada Olahraga. Bandung: Fakultas Pendidikan Olahraga dan Kesehatan UPI.

Sheffer AL. (1992). International consensus Report on Diagnosis and management of Astma. US Departement of Health and Human Services. Clinical and Experimental Allergy, Vol. 2. Suppl. I.

Soena Stxmantri ES.(1995). Epidemiologi asma di Indonesia. Buku Makalah Lengkap Penemuan Ilmiah Recent Advances In Respiratory Medicine. Konkemas Perkumpulan Dokter Paru Indonesia

Sri Astuti Suparmanto. (1994). Dirjen Pelayanan Medik (Yanmed) Departemen Kesehatan. Jakarta.

Van (2004). Penyakit asma banyak diderita oleh anak-anak. Sinar Harapan: Jakarta

Wara Kushartanti. (2002). Olahraga Terapi Yogyakarta: Fakultas Ilmu Keolahragaan UNY

Wisnu Wardoyo. (2003). Revitalisasi Senam Penyembuhan Medica. Yogyakarta: SPa Medica

Woolcock A. (1994). Epidemiology asthma - worldwide trends. Airways in asthma. Effects of treatment. Penang Malaysia. Excerpta Medica 
Zul Dảhlan (2005). Masalah Asma di Indonesia dan Penaggulangannya. Bandung: Fakultas Kedokteran Universitas Padjadjaran

http://www.medicastore.com/neo_napacin/senam_asma.htm

MED I KORA Vol. V, No 1, April 2009: 71-91 